\title{
LANGUAGE DIVERSITY IN SYAIR NASIHAT: AN ALTERNATIVE EFFORT TO STRENGTHEN NATIONAL IDENTITY THROUGH LITERATURE LEARNING
}

Keberagaman Bahasa dalam Syair Nasihat:

Sebuah Upaya Alternatif Memperkuat Jati Diri Bangsa melalui Pembelajaran Sastra

\section{Asep Yudha Wirajaya, Bani Sudardi, Istadiyantha, dan Warto}

Universitas Sebelas Maret

Jalan Ir. Sutami No.36, Kentingan, Kec. Jebres, Kota Surakarta, Jawa Tengah, Indonesia asepyudha.w@gmail.com

\begin{abstract}
Abstrak
Syair Nasihat (selanjutnya disingkat $S N$ ) merupakan karya sastra lama yang ditulis dengan huruf Arab dan memanfaatkan keragaman bahasa yang ada di Nusantara. Oleh karena itu, kajian terhadap naskah $S N$ perlu dilakukan secara komprehensif dan holistik sehingga keragaman bahasa yang dimanfaatkan untuk menanamkan nilai-nilai kearifan lokal tersebut dapat dijadikan sumber inspirasi bagi pembelajaran sastra di masa yang akan datang. Adapun metode yang digunakan dalam kajian ini adalah metode penyuntingan teks, yaitu metode edisi kritis. Penggunaan metode ini diharapkan dapat menghadirkan suntingan teks $S N$ yang baik dan benar. Adapun metode pengkajian teks yang digunakan adalah metode penelitian sastra, khususnya kajian semiotik. Dengan demikian, penggunaan bahasa beserta simbol-simbolnya yang terdapat dalam teks $S N$ dapat diungkap secara tuntas sehingga hasil kajiannya dapat bermanfaat bagi dunia pendidikan dalam menyambut Revolusi Industri 4.0 dan Society 5.0 .
\end{abstract}

Kata-kata kunci: Syair Nasihat, keragaman bahasa, jati diri bangsa, pembelajaran, sastra

\section{Abstract}

Syair Nasihat (hereinafter abbreviated as SN) is an old literary work written in Arabic letters and utilizing the diversity of languages that exist in the archipelago. Therefore, a study of the SN manuscript needs to be carried out comprehensively and holistically so that the diversity of languages used to instill the values of local wisdom can be used as a source of inspiration for literary learning in the future. The method used in this study is the text editing method, namely the critical edition method. The use of this method is expected to provide good and correct $S N$ text edits. The text study method used is a literary research method, especially semiotic studies. Thus, the use of language and its symbols contained in the SN text can be fully disclosed so that the results of the study can be useful for the world of education in welcoming the Industrial Revolution 4.0 and Society 5.0.

Keywords: Syair Nasihat, language diversity, national identity, learning, literature

How to Cite: Wirajaya, Asep Yudha, dkk. (2021). Language Diversity in Syair Nasihat: An Alternative Effort to Strengthen National Identity through Literature Learning. Ranah: Jurnal Kajian Bahasa. 10(2). 314-325. doi: https: https://doi.org/10.26499/rnh.v10i2.4052 


\section{INTRODUCTION}

Syair Nasihat (hereinafter abbreviated as $S N$ ) is one of the ancient manuscripts found in Bali on April 10, 1857 AD (Anonim, 1857). This manuscript was written using dluwang paper media, written in Arabic and Malay (Effendi \& Wirajaya, 2019). Of course, the manuscript is one of the interesting manuscripts to study, considering: first, in general, Balinese manuscripts are written using lontar media, in Javanese or Sanskrit script (Pigeaud, 2016; Zoetmulder, 1983). Second, the contents of the $S N$ manuscript are Islamic teachings, even though the majority of the Balinese population are Hindus (Mashad, 2014). Third, the use of the language contained in the $S N$ text turns out to be not only Malay but also several regional languages (besides Balinese) and foreign languages (Arabic and Dutch) (Hidayat, Roch Aris, 2020).

Manuscripts with the theme of Islam in Bali, are valuable relics and of course also part of the Nusantara manuscripts. These manuscripts are evidence of the development of the culture of writing with Arabic script in line with the development of Islam in Bali. Thus, the manuscript is a cultural document that stores a lot of important information about many things about the life of the people of the past. These manuscripts are also able to provide information about the development of their religious and religious life, their spiritual life, and their intellectual life (Hidayat, Roch Aris, 2020).

In other words, the existence of this $S N$ manuscript can at least be an important historical document related to the formation of Islamic scholarly and scholarly traditions in the archipelago of Southeast Asia. Of course, this cannot be separated from the dynamics of Islam, both at the local, regional, and global levels. The rise of the ulama network in Haramain since the end of the 15th century has attracted more and more students from various regions of the Muslim world, including the archipelago in it. At least since the end of the 16th century, students from the archipelago began to come to Haramain. They came to be known as "students of Jawi" (ashab al-Jawiyyin) (Azra, 2002). Then, they formed a network of scholars and students who spread to the Indian Ocean region. They also play a very important role in the renewal of Islamic discourse and praxis, both at the local, regional, and global levels (Widiyatmoko, 2018). The religious reforms they introduced were centered on harmonization between sharia and Sufism and the social reconstruction of the Muslim community (Azyumardi Azra, 2016).

Thus, examining the existence of the $S N$ manuscript is expected to provide a complete, complete, and comprehensive picture of Bali, multiculturalism, and cosmopolitanism in the 1819 century AD (Azyumardi Azra, 2016). This is important, considering the increasing threat of national disintegration, especially during a recession due to the ongoing COVID-19 pandemic. This means that the COVID-19 pandemic not only threatens the existence of human life, community but also threatens the existence of a nation and state (Žizek, 2020). Therefore, by studying the SN manuscript, it is hoped that the values of local wisdom contained in the text can be used as an alternative source of inspiration for strengthening national identity through literary learning.

\section{THEORETICAL BASIS}

Research on the existence of Islamic-themed manuscripts in Bali is an effort by the research team of the Research and Development Center for Religion - Semarang - Central Java to take stock of the existence of Islamic manuscripts that are still scattered throughout the island of Bali (Hidayat, Roch Aris, 2020). Of course, this initial step is a serious effort to reveal the existence of Islam in the Hindu community in Bali. It is an undeniable fact that Islam has been present in Bali and has left traces of many manuscripts. This fact will certainly have a much more important meaning when the fact is placed in a wider context, namely the relationship between the majority - Muslim minority - Hindus in Bali as a socio-religious phenomenon 
(Muljana, 2012; Suhardana, 2008). Based on the results of the inventory, at least 140 Islamicthemed manuscripts have been found and digitized, both in private collections and in community collections in Muslim villages in Bali.

Talking about Islam in Bali as a minority religion is, of course, different from Islam as the majority religion. Islam as a minority will display its figure who is in the shadow of the hegemony of the majority. This is of course very well realized by Muslim leaders who live together with the Hindu community as the majority group. Therefore, there will be boundaries that are difficult - if not impossible - to be crossed by the Muslim community as a minority (Hidayat, Roch Aris, 2020; Mashad, 2014).

Manassa (the Archipelago Manuscript Society) conducted a search and mapping of the Balinese manuscript treasures in 2009 - 2010. The collection of information started from existing data, namely from various catalogs of manuscripts that had been published or printed. In the next step, the team contacted people who allegedly knew information about the existence of the manuscript in an area and had access to the owner of the manuscript. The results of the data collection show that Bali ranks first as the largest manuscript storage area in Indonesia, which is 31,091. Thus, the number of manuscripts stored in Bali is about 2.5 times more than the number of manuscripts stored in the National Library of the Republic of Indonesia - the state institution that stores the largest manuscripts in Indonesia. This data is actually not too surprising because some Balinese people in some areas are still actively copying manuscripts for various purposes (Azra, 2002). The focus of the research at that time was to examine various Balinese manuscripts which allegedly contained Islamic stories to see the relationship between Islam and Balinese culture and relate it to national integration and social harmony (Holil, 2020).

The history of the entry of Islam into a number of areas in Bali is indeed not a unified whole (Mashad, 2014). That is, the history of the arrival of Islam to the Bali region occurred in waves, not in the same period, and occurred for various different reasons (Khusyairi, Johny Alfian, 2017). Thus, between one community in one area and another, there is almost no strong relationship (Assegaf, 2012; Mashad, 2014).

Of the entire Balinese Islamic community, the Gelgel Muslim, which is now located in Klungkung Regency, in historical records is the oldest in history. Those who mainly live in Gelgel are even listed as the generation of Muslim pioneers in the Bali region in general. The arrival of the earliest generation of Muslims was conducted by the Javanese before the reign of Dalem Waturenggong (1460 - 1550 AD) or to be precise the era of Dalem Ketut Ngelesir (1380 - 1460 AD) which coincided with the era of Hayam Wuruk ruling Majapahit (1350 - 1380 AD). Dalem Ketut Ngelesir paid a visit to Majapahit when Prabu Hayam Wuruk held a conference of vassal kingdoms (conquered) throughout the archipelago in the early 1380s AD. When he returned to Gelgel, Dalem Ketut Ngelesir was given Prabu Hayam Wuruk 40 companions who were all Muslim (Agung, 1989; Ardika, I Wayan, I Gde Parimartha, 2018; Assegaf, 2012; Mashad, 2014; Muljana, 2012; Shastri, 1963; Widiyatmoko, 2018; Wikarman, 1998).

The 40 Muslims who accompanied Ngelesir from Majapahit finally settled and acted as courtiers of the Gelgel kingdom. The forty people occupy a residential area given by the king and are married to local women. They built the Gelgel Mosque, as well as being the oldest mosque in Bali. Since then, the Muslim community began to exist in Bali. The Gelgel area still exists today, which is administratively included in the Klungkung district (Mashad, 2014).

As for the study of the SN manuscript Djamaris (1986), In addition, the $S N$ manuscript has also been studied by Wirajaya (1999) who produced text edits from two manuscripts and functional analysis, and Wirajaya (2014) who presented text edits from three manuscripts accompanied by semiotic analysis. Thus, a study of the diversity of languages contained in the $S N$ text has never been conducted at all. 


\section{RESEARCH METHOD}

In general, this research uses a descriptive qualitative method. The qualitative method is a research procedure that produces descriptive data, both in the form of written and spoken words from people and observed behavior (Haris Herdiansyah, 2012; Mohamed, Z. M., Abdul Majid, A. H., \& Ahmad, 2010; Taylor, S. J., \& Bogdan, 1998). Regarding the handling of the SN manuscript, a philological research method will be used, namely the critical edition (Djamaris, 2002; Fathurahman, 2015; Ikram, 2019). Then, the edited $S N$ text that is good and correct will be classified based on its type and analyzed using a descriptive-analytical approach, namely describing the data that has been collected and analyzing it. This semiotic analysis is intended to reveal the functions and meanings behind the use of language diversity in the $S N$ text (Ratmanto, 2004; Riffaterre, 1978). The results of this analysis can then be used as an alternative reference for solving various problems the nation is currently facing (Huberman, 1992; Pitana, 2014).

\section{DISCUSSION}

\section{Overview of Manuscripts in Bali}

Historically, Bali has a wealth of history that is quite diverse. The influx of Javanese, Lombok, Bugis, and others to Bali gave a more varied historical contribution to the history of Bali. Their arrival to Bali in addition to trading also spread religion, including Islam (Mashad, 2014; Muljana, 2012; Widiyatmoko, 2018). The long period in the process of their arrival to Bali indicates that many historical traces can be used as sources of information in the search for religions in Bali, including Islam (Ardika, I Wayan, I Gde Parimartha, 2018; Hidayat, Roch Aris, 2020). Tracing the traces of Islam in Bali can be done by collecting information about the existence of the Muslim community in Bali (Hidayat, Roch Aris, 2020; Mashad, 2014).

In this Muslim community, Islam developed through da'wah activities carried out by religious leaders. Their da'wah pattern is carried out directly through lectures, recitations, and educational institutions. In addition, they also carry out da'wah activities indirectly through writing books, copying the Qur'an, and building places of worship, such as mosques and prayer rooms (Hidayat, Roch Aris, 2020; Hidayat, 2019).

Da'wah activities through writing or copying the Qur'an and other religious books are thought to have been going on since the beginning of the arrival of Muslims in Bali. This can be understood because Islam is a da'wah religion so that everyone who claims to be Muslim must convey Islamic teachings to everyone (Hidayat, 2019). This tradition of copying and writing was carried out by groups of nobles and ordinary people. In the aristocratic group, including merchants, the tradition of copying was carried out in the castle or studio belonging to the king or noble family, using European paper writing instruments and relatively better writing instruments. As for the copying for ordinary people, the tradition is carried out in private homes or places of worship, using dluwang paper, and makeshift writing utensils (Hidayat, Roch Aris, 2020).

Of course, this fact further strengthens Bali as an area that has a strong script tradition and even continues to this day. The Balinese manuscript tradition that is widely known today is a manuscript tradition that continues the tradition of Old Javanese and Kawi literary manuscripts. The tradition of reading, copying, and adapting religious books, both Hindu and Buddhist in Central and East Java using Old Javanese and Kawi literature, was continued in Bali (Suhardana, 2008). The tradition that lasted between the 10th century AD to the 15th century AD was continued until the emergence of the Islamic kingdom of Demak (Zoetmulder, 1983). Furthermore, this tradition has been continued in Bali on a limited basis until now, both in terms of reading, copying, and adapting (Chambert-Loir, Henri, 1999). 
The languages used in the Balinese manuscript tradition are generally Sanskrit, Old Javanese, Central Javanese, and Balinese (Chambert-Loir, Henri, 1999; Hidayat, Roch Aris, 2020; Meij, 2004, 2017; Pigeaud, 2016). Even in terms of materials, the Balinese manuscript tradition still retains a lot of the materials used in the Old Javanese manuscript tradition, namely lontar (Jirnaya, 2015; Pigeaud, 2016; Robson, 1994). The following is the distribution of manuscripts in Bali (Chambert-Loir, Henri, 1999).

Table 1 .

Distribution of Manuscripts in Bali

\begin{tabular}{llrr}
\hline No & \multicolumn{1}{c}{ Collection } & Quantity & \multicolumn{1}{c}{$\%$} \\
\hline 1 & Archeology Center - Denpasar & 3 & 0,05 \\
2 & Language Research Institute - Denpasar & 156 & 2,68 \\
3 & Faculty of Cultural Sciences - Udayana University & 740 & 12,73 \\
4 & Gedong Kirtja - Singaraja & 3.081 & 53,04 \\
5 & Bali Province State Museum & 266 & 4,58 \\
6 & Bali Cultural Documentation Center & 1.416 & 24,37 \\
7 & Indonesian Hindu University & 148 & 2,55 \\
\hline
\end{tabular}

In addition, in terms of content, it is more nuanced in Hinduism because many Balinese people embrace Hinduism (Jirnaya, 2015). However, a small part of the Balinese manuscript treasure contains Islamic teachings or Islamic nuances. This was stated by Hakam (2017) although only a few Islamic religious manuscripts have been found and described. However, it is important to pay attention to Islamic manuscripts in the context of Balinese culture and manuscript traditions. The focus of attention on Balinese manuscripts which are Hindu-styled and contain only Hindu teachings is not unimportant, but attention to Islamic manuscripts amid Balinese manuscript traditions which are more Hindu-style can show the dialectic of religions within a certain cultural sphere (Hidayat, Roch Aris, 2020).

\section{Use of Regional Languages in SN Texts}

As previously stated, the diversity of languages contained in the Balinese manuscript tradition is a necessity (Pigeaud, 2016). Thus, in the Balinese manuscript tradition, at least the plurality is an extraordinary spiritual wealth. This diversity has unwittingly been used, both as a means and media for learning, da'wah, as well as cross-cultural and inter-religious communication or beliefs (Pigeaud, 2016; Zoetmulder, 1983). Therefore, it is necessary to pay closer attention to this linguistic phenomenon about religious dialectics in Bali. The following is the use of regional languages found in the $S N$ text.

\section{Table 2 .}

Use of Regional Languages in $S N$ Texts

\begin{tabular}{llcll}
\hline No & Vocabulary & Frequency & Islam & Meaning \\
& & & & Hindu \\
\hline 1 & sembahyang & 13 & shalat & worship Hyang \\
2 & puasa & 6 & shaum or shiyam & upawasa \\
3 & sugih & 2 & rich is (wealth) more than need & artha (property) \\
\hline
\end{tabular}

Based on the table, at least it can be seen that there is the use of Javanese in the $S N$ text. That is, the data strengthens Pigeaud (2016) thesis which states that Javanese is one of the languages whose writing tradition is continuing to be used in Balinese manuscripts. The following is a quote in the $S N$ text.

you learn the arguments and hadiths

don't sleep until the day is high

wake up praying in the morning

not preceded by the sun $\quad(S N$, p. 19)

pray five times don't be lazy

do him sincerely and sincerely

don't want to reply right away

to everything called human $\quad(S N$, p. 20) 
Based on these quotes, it can be seen that the author of the $S N$ manuscript prefers the word "prayer" over the word "prayer" to introduce the concept of worshiping Allah SWT - God Almighty. Etymologically, the word "prayer" consists of two words, namely "worship" (meaning worship activities) and "Hyang" (meaning God) (Tim, 2020). The concept of "prayer" is closer to Hindu teachings. But in its development, the concept was then borrowed and used by Islamic preachers to spread or teach Islamic values (Azra, 2002; Fang, 2013; Winstedt, 1991; Wirajaya, 2019).

In addition, the SN text also found the use of the word "fasting" to replace the word "shaum" or "shiyam". While the concept of "fasting" was already known in Hinduism as "upawasa". This can be seen through the following quote.

you should eat less

all sunnah fasting is good you do

you keep your tongue

useless stuff don't you say

$(S N$, p. 19)

looking for art hard

leave prayer by fasting

your age is over you don't feel

in the hereafter will feel the torment $(S N$, p. 23)

Based on the quote from the stanza, it is known that the author of the $S N$ manuscript prefers the word "fasting". In fact, in the concept of Islamic teachings, what is in the quotations, both the hadith and the Qur'an is the word "shiyam" or "shaum". The word "shaum" or "shiyam" is interpreted by imsak which means to hold back. In the Qur'an the word "shaum" shows a more general meaning than "shaum" which is often used to indicate a more specific meaning, namely fasting by refraining from eating and drinking and restraining lust from sunrise to sunset (Mustinda, 2021).

In this context, once again the author of the $S N$ manuscript wants to introduce and bring Islamic teachings closer to the Hindu community. Therefore, he prefers the word "fasting". If the word "fasting" is traced in the Balinese dictionary, it will be found that fasting means kenta, brata, and tapa, while in the Hindu religious concept the meaning of fasting has a different meaning because the word "fasting" comes from Sanskrit which consists of the word "fasting". "Upa" and "wasa": "upa" means "near" or "closer", and "wasa" means God Almighty. So, the point is that it is an effort to get closer to God Almighty, which means worshiping His majesty by not eating and not drinking for 24 hours. In addition, these activities are accompanied by applying Hindu religious teachings in terms of controlling the five senses, namely controlling lust, or being able to control thoughts and desires. Thus, carrying out "fasting" in the teachings of Hinduism in Bali, not only not eating and drinking. However, there is a deep meaning and wisdom that must be implemented in terms of self-control, to curb lust, to achieve peace and harmony in life (Kusniarti, 2021).

As for the context of the word "sugih" it can be seen through the $S N$ text excerpt as follows.

very magical people who are Richman

make a big and tall house

have jewelry

nobody loses alone

$(S N$, p. 27)

very magical to Richman

people who give alms are said to have lost

don't know where to go

rewarded in various ways $\quad(S N$, p. 33) 
Based on the quote, it can be seen that the word "sugih" is used by the $S N$ manuscript writer to describe rich people. The meaning of the word "sugih" in the Big Indonesian Dictionary (KKBI) is to be rich and have a lot of wealth (Tim, 2020). In the concept of Hinduism, "rich" is called Artha (wealth). Artha is part of Catur Purusa Artha, namely the four goals of life in the teachings of Hinduism, namely dharma, artha, kama, and moksa. The fourth purpose of Hindu life, wealth (artha) is the goal of human life. So there is nothing wrong if a Hindu is rich because that is the purpose of human life according to the concept of Moksartham Jagadhita ya ca iti dharma. Physical happiness (jagadhita) is the goal of one's life. The way to become rich according to the Hindu view certainly cannot be separated from the teachings of Catur Marga Yoga, namely the four paths to immortality (moksa). Because no one can get freedom if his life is suffering. For that, it is very important to understand Catur Purusa Artha. So, being rich in Hinduism is not only in the form of the property but also rich in knowledge, ethics, morals, and so on (Indah, 2020).

As for the rich in the Islamic concept is a person who has more wealth than his needs. However, in the inner meaning, rich is a person who is grateful and not a matter of how much wealth. In the inner meaning, being rich feels enough to maintain 'iffah (restraint) and selfrespect. Meanwhile, from the definition of ownership, rich is (wealth) that is more than a need. Therefore, what must be pursued by a Muslim is the wealth of the heart and wealth of wealth. Rich in heart of course with a lot of gratitude and qana'ah, which means accepting God's gift. and return to Him by being grateful for all the favors or gifts he has received. The assets collected must of course be in a lawful and good way. Then, the assets owned are donated (zakat, wakaf, infaq, and sedekah). This is an obligation that must be fulfilled by a Muslim if he already has sustenance in the form of abundant wealth. Thus, the teaching of zakat can only be done by the rich, while the poor will not be able to pay zakat. So actually Islam prefers rich people because the hand that gives is better than the one who receives it. In that context, what is not allowed is to become rich with pride. As for what is needed is rich and ascetic, living life with simplicity. So it is better for generous rich people, their lives are simple, that is what the Messenger of Allah wanted. so that he can pay tithe, donate, give charity, for good (Mukhtar, 2021).

Thus, the author or copyist of the $S N$ manuscript has a good understanding of the target audience for their work, the majority of whom are Hindus. Therefore, the author of the $S N$ manuscript prefers a diction that is more familiar with the world of hearing and their daily world. It is intended that the concepts of Islamic teachings that have similarities with Hindu teachings can be well received. Of course, this is an excellent form of da'wah strategy to minimize unnecessary debates (Azra, 2002; Fang, 2013; Winstedt, 1991; Wirajaya et al., 2020). This can be understood considering that Islam in Bali is a minority religion when compared to Hinduism (Yahya, 2021). The following is a statistical table of the number of religious adherents in Bali.

Table 3.

Number of Religious Adherents in Bali

\begin{tabular}{llrr}
\hline No & & Religion & $\begin{array}{c}\text { Amount } \\
\text { Adherents }\end{array}$ \\
\hline 1 & Hindu & 3.247 .283 & \multicolumn{1}{c}{$\%$} \\
\hline 2 & Islam & 520.244 & 13,390 \\
3 & Christian Protestant & 64.454 & 1,659 \\
4 & Catholic & 31.397 & 0,808 \\
5 & Buddha & 21.156 & 0,545 \\
6 & Confucianism & 427 & 0,013 \\
7 & Etc & 282 & 0.007 \\
\hline
\end{tabular}


In addition, it seems that the author of the $S N$ manuscript has also considered aspects of the ethnic groups who came to Bali (Yahya, 2021). This can be seen through the following table.

Table 4.

\begin{tabular}{clc}
\multicolumn{2}{c}{ Number of ethnic groups inhabiting the island of Bali } \\
\cline { 1 - 3 } No & \multicolumn{1}{c}{ Ethnic Group } & \% \\
\hline 1 & Bali asli & 84.96 \\
2 & Bali Aga & 0.40 \\
3 & Jawa & 9.60 \\
4 & Madura & 0.77 \\
5 & Melayu & 0.59 \\
6 & Sasak & 0.58 \\
7 & NTT & 0.50 \\
8 & Tionghoa & 0.38 \\
9 & Sunda & 0.30 \\
10 & Bugis & 0.24 \\
11 & Batak & 0.17 \\
12 & Etc & 1.51 \\
\hline
\end{tabular}

\section{Use of Foreign Languages in SN Texts}

In addition to regional languages, the use of foreign languages is also found in the $S N$ text. Based on the results of observing the $S N$ text, it is known that there is the use of Arabic and Dutch. However, this discussion will focus on the phenomenon of the use of the Dutch language found in the $S N$ text. The use of Dutch in the $S N$ text can be seen through the following quotation.

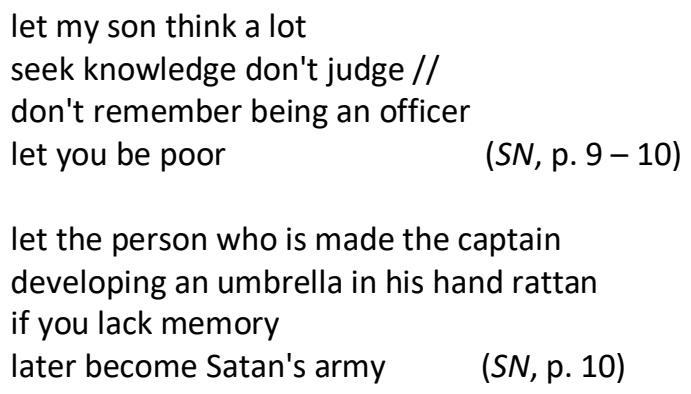

Based on these quotes, it can be seen that there is a use of the Dutch language, namely "opsir" and "kapitan". According to the Big Indonesian Dictionary (KBBI), the meaning of the word "kapitan" is the title (designation) of the regional head during the reign of the king, at the level of the sub-district head in East Nusa Tenggara and Maluku. Another meaning of "kapitan" is the head of the Chinese population group (during the Dutch colonial era). In addition, the word "kapitan" is also included in a variety of archaic languages (Tim, 2020). The word "opsir", according to the Big Indonesian Dictionary (KBBI), means officer (rank in the military). "Opsir" has meaning in the noun or noun class so that the officer can state the name of a person, place, or all things and everything that is objectified. The word "opsir" is also included in a variety of archaic languages (Tim, 2020). The following table is related to the use of foreign languages.

Table 5

Use of Foreign Languages in $S N$ Texts

\begin{tabular}{llcl}
\hline No & Vocabulary & Frequency & Meaning \\
\hline 1 & $\begin{array}{l}\text { opsir } \\
\text { kapitan }\end{array}$ & 1 & $\begin{array}{l}\text { officer (rank in the military) } \\
\text { 1) the title (designation) of the regional head during the reign of the king, at } \\
\text { the same level as the sub-district head in the areas of East Nusa Tenggara } \\
\text { and Maluku. }\end{array}$ \\
\hline
\end{tabular}


Thus, the quote actually wants to give an illustration that in the 18-19 century AD in Bali there had been contacted, both trade and politics with outside parties, namely China and the Netherlands. This is reinforced by the statement of Ricklefs (2007) which confirms that since the 18th century AD, the VOC has been searching for slaves in Bali, which will then be used both for labor on the VOC plantations and for the benefit of the army in wars. in Java. At that time it was well known that Balinese men were very brave and mighty in the war. This also caused a large number of Balinese to settle around Batavia and in the 18th century, the number was estimated at 13,200 people (Agung, 1989; Ardika, I Wayan, I Gde Parimartha, 2018).

This policy of recruiting soldiers from the local community had to be carried out by Daendels upon arrival in Java as an anticipatory measure and a strategy to deal with the British invasion plan in Java. The addition of the number of reserve troops from the local community component must be carried out immediately considering that if you have to bring in troops from the Netherlands, you will experience many obstacles because of the British blockade at sea (Agung, 1989). In fact, in 1824, an Arab descendant, named Prince Said Hasan al-Habsyi was also sent to Bali by the Dutch to approach the King of Badung, to obtain slave labor to be trained as war soldiers. On that occasion, the kings of Bali did not seem sympathetic to the arrival of the envoy, except for the King of Badung who was willing to accept. To strengthen his relationship with Badung, in 1826 a Dutch envoy was also sent to Badung, namely Captain J.S. Wetters. On January 2, 1827, Captain J.S. Wetters succeeded in contracting to get army candidates from the King of Badung (Ardika, I Wayan, I Gde Parimartha, 2018).

Before the British Government came to power in the archipelago, the slave trade was an illegal activity and was strictly prohibited. However, Bali was a bustling slave trade market. Many Balinese men and women were trafficked as slaves to Batavia because they were well known as diligent, diligent, and honest workers. In addition, many Balinese are trafficked to the islands of Bourbon and Mauritius for work on sugar cane plantations. Based on Raffles' research, it is known that the price of a male slave in Bali before this trade was abolished was 10-30 dollars per person, while the price of a female slave was 50-100 dollars (Raffles, 1817). It is estimated that from Badung alone, every year around 400 slaves are traded outside Bali for 20 dollars (ringgit), so this means that the income for the king from the slave-trading sector reaches 8,000 dollars (ringgit) (Agung, 1989). Thus, the $S N$ text not only shows the use of foreign languages but also describes the Balinese context in the constellation of trade and politics that occurred around the 18th-19th centuries.

\section{CLOSING}

Based on the previous description, it can be concluded as follows. First, the existence of the $S N$ manuscript in Arabic and Malay script and using dluwang paper in Bali is a very important cultural and historical document. This is based on the fact that Balinese manuscripts are more dominated by Javanese, Old Javanese, or Sanskrit scripts with the media in the form of lontar. In addition, the existence of the $S N$ manuscript is also very meaningful for the development of multiculturalism in the archipelago amid the threat of national disintegration.

Second, the use of regional languages found in the $S N$ text is at least based on reasons of convenience and practicality for the ulama in spreading or teaching Islamic values to the Balinese people. This cannot be separated from the context that Bali and Java have a very strong historical and emotional relationship. The choice of Javanese language was also carried out because the values of Islamic teachings have a close meaning and meaning with the values of Hindu teachings. In addition, the choice of diction is done to avoid unnecessary debates.

Third, the use of foreign language diction, in this case, Dutch can be understood as part of the representation of cultural and trade contacts between Balinese people and the outside 
world. So, through this $S N$ manuscript, at least a lesson can be taken about our history and identity as a pluralistic nation with various cultures, languages, and customs.

\section{BIBLIOGRAPHY}

Agung, I. A. A. G. (1989). Bali in the XIX Century: The Struggle of the People and the Kings Against Dutch Colonialism 1808 - 1908. Gadjah Mada University Press.

Anonim. (1857). Syair Nasihat. Perpustakaan Nasional Republik Indonesia.

Ardika, I Wayan, I Gde Parimartha, A. A. B. Wi. (2018). History of Bali: from Prehistoric to Modern. Udayana University Press.

Assegaf, C. T. Z. A. (2012). The History of the Tomb of Sab'atul Aulia' Wali Pitu in Bali. Zifatama Publisihing.

Azra, A. (2002). Islam Nusantara: Global and Local Network. Mizan.

Azyumardi Azra. (2016). Jaringan Ulama Nusantara. In Islam Nusantara: dari Ushul Fiqh Hingga Paham Kebangsaan. Mizan.

Chambert-Loir, Henri, O. F. (1999). Treasures of Manuscripts: A Guide to the World's Manuscript Collection. Ecole francaise d'Extreme-Orient dan Yayasan Obor.

Djamaris, E. (1986). Puisi Indonesia Lama Berisi Nasehat: Koleksi Naskah Museum Nasional. Departemen Pendidikan dan Kebudayaan - Proyek Penerbitan Buku Sastra Indonesia dan Daerah.

Djamaris, E. (2002). Philology Research Methods. Monasco.

Effendi, M. Z., \& Wirajaya, A. Y. (2019). Kajian Resepsi Terhadap Teks Futūhu '1- 'Ārifīn. Jumantara: Jurnal Manuskrip Nusantara, 10(2), 209-224. https://doi.org/10.37014/jumantara.v10i2.534

Fang, L. Y. (2013). A History of Classical Malay Literature. Institute of Southeast Asian Studies Singapore Publishing \& Yayasan Pustaka Obor Indonesia. https://doi.org/10.1355/9789814459891

Fathurahman, O. (2015). Indonesian Philology: Theory and Method. Prenadamedia Group and UIN Jakarta.

Hakam, S. (2017). Kesusastraan Melayu dan Perannya dalam Dunia Islam Nusantara. Jurnal Ilmu Agama: Mengkaji Doktrin, Pemikiran, Dan Fenomena Agama, 18(2), 74-82. https://doi.org/10.19109/jia.v18i2.2365

Haris Herdiansyah. (2012). Metodologi Penelitian Kualitatif. Salemba Humanika. https://doi.org/10.20414/ujis.v16i1.187

Hidayat, Roch Aris, et. al. (2020). Jejak Islam dalam Manuskrip di Bali. DIVA Press.

Hidayat, K. (2019). Religion for Civilization: Grounding Religious Ethos in Life. Pustaka Alvabet.

Holil, M. (2020). Introduction Chairman of the Archipelago Manuscript Society (Manassa). In Traces of Islam in Manuscripts in Bali (pp. vii-x). DIVA Press.

Huberman, M. B. M. dan A. M. (1992). Analisis Data Kualitatif: Buku Sumber tentang Metodemetode Baru. UI Press.

Ikram, A. (2019). Introduction to Philological Research. Archipelago Textbook Society.

Indah. (2020). tiga cara memperoleh kekayaan dalam agama Hindu. 07 Oktober 2020. https://brainly.co.id/tugas/34167181

Jirnaya, I. K. (2015). Sinkretisme Hindu-Islam dalam Mantra: Sebuah Kasus dalam Teks Usada Manak. Adabiyyāt: Jurnal Bahasa Dan Sastra, 14(2), 282-300. https://doi.org/10.14421/ajbs.2015.14206

Khusyairi, Johny Alfian, dkk. (2017). Sailing to the Island of the Gods: The Bugis-Makassar \& Mandar Diaspora on the Island of Bali. Ombak.

Kusniarti, S. A. A. (2021, May 28). Mutih, Berikut Makna Puasa dalam Agama Hindu - 
Halaman 2 - Tribun Bali. 28 Mei 2021, 2. https://bali.tribunnews.com/2021/05/28/mutihberikut-makna-puasa-dalam-agama-hindu?page $=2$

Mashad, D. (2014). Balinese Muslims: Recovering Lost Harmony. Pustaka Al-Kautsar.

Meij, D. van der. (2004). Pluralism and Identity in the Indonesian-Malay World: The Isrā' Mi'rāj as a token of both. Studia Islamika, 11(3). https://doi.org/10.15408/sdi.v11i3.595

Meij, D. van der. (2017). Indonesian Manuscripts from the Islands of Java, Madura, Bali, and Lombok. Brill.

Mohamed, Z. M., Abdul Majid, A. H., \& Ahmad, N. (2010). Tapping New Possibility in Accounting Research, in Qualitative Research in Accounting, Malaysian Case. Universiti Kebangsaan Malaysia.

Mukhtar, U. (2021, April 14). Kaya dalam Kacamata Islam. 14 Apr 2021, 1. https://www.republika.id/posts/15823/kaya-dalam-kacamata-islam

Muljana, S. (2012). The Fall of the Hindu-Javanese Kingdom and the Rise of Islamic Countries in the Archipelago (M. Al-Fayyadl (ed.)). LKiS.

Mustinda, L. (2021, April 1). Arti Puasa Menurut Istilah, Bahasa dan Keutamaannya. 1 Apr 2021, 1. https://www.detik.com/edu/detikpedia/d-5516873/arti-puasa-menurut-istilahbahasa-dan-keutamaannya

Pigeaud, T. G. T. (2016). Literature of Java: Catalogue Raisonné of Javanese Manuscripts in the Library of the University of Leiden and Other Public Collections in the Netherlands. Leiden University Libraries. http://hdl.handle.net/1887.1/item:114875

Pitana, T. S. (2014). Teori Sosial Kritis: Metode dan Aplikasinya. STAIN Press bekerja sama dengan MITRA MEDIA.

Raffles, S. T. S. (1817). The History of Java. Black, Parry and Co.

Ratmanto, T. (2004). Pesan: Tinjauan Bahasa, Semiotika, dan Hermeneutika. MediaTor, 5(1), 29-37. https://doi.org/https://doi.org/10.29313/mediator.v5i1.1095

Ricklefs, M. C. (2007). History of Modern Indonesia 1200 - 2004 (H. Syawie (ed.); Ketiga). Serambi Ilmu Semesta.

Riffaterre, M. (1978). Semiotics of Poetry. Indiana University Press.

Robson, S. O. (1994). Prinsip-prinsip Filologi Indonesia. RUL.

Shastri, N. D. P. (1963). History of Bali Dwipa. Bhuvana Saraswati Publishing.

Suhardana, K. M. (2008). Negarakretagama \& Pararaton: History of Majapahit Development. Paramita.

Taylor, S. J., \& Bogdan, R. (1998). Introduction to Qualitative Research Methods: A Guidebook and Resource (3rd ed.). John Wiley \& Sons Inc.

Tim. (2020). Kamus Besar Bahasa Indonesia Versi Online. Badan Pengembangan Dan Pembinaan Bahasa, Kemdikbud. https://kbbi.kemdikbud.go.id/

Widiyatmoko, B. (2018). The Chronicle of the Transition of the Archipelago: The League of Kings to Colonial. Mata Padi Presindo.

Wikarman, I. N. S. (1998). Balinese Ancestors: From the World of Babad and History. Paramita.

Winstedt, R. (1991). A History of Classical Malay Literature. Oxford University Press.

Wirajaya, A. Y. (1999). Syair Nasihat: Suntingan Teks dan Analisis Fungsi. Universitas Sebelas Maret.

Wirajaya, A. Y. (2014). Syair Nasihat: Suntingan Teks Disertai Analisis Struktural-Semiotik. Universitas Gadjah Mada.

Wirajaya, A. Y. (2019). Poetic Aesthetics of Classical Malay Literature. Library Oasis.

Wirajaya, A. Y., Sudardi, B., Istadiyantha, \& Warto. (2020). Representation of the Communication Strategy for the Da'wah of the Sufi Order in Syair Nasihat as an Effort to Strengthen National Unity. Proceedings of the 6th International Conference on Social and 
Political Sciences (ICOSAPS 2020). https://doi.org/10.2991/assehr.k.201219.010

Yahya, H. (2021). Bali Province in Figures 2021. Statistics of Bali Province. https://bali.bps.go.id/publication/2021/02/26/4ae96914ff22e9b79d8d6551/provinsi-balidalam-angka-2021.html

Žizek, Sl. (2020). Pandemic! Covid-19 Shakes the World. OR Books. https://doi.org/10.2307/j.ctv16t6n4q

Zoetmulder, P. J. (1983). Kalangwan: A survey of old Javanese literature (Koninklijk Instituut voor Taal-, Land- en Volkenkunde. Translation series; 16). Djambatan. 